Department of Anatomy (Prof. Y. Sano), Kyoto Prefectural University of Medicine, Kyoto, Japan

\title{
An Experimental Study on the Sympathetic Neuron Chains Using the Fluorescence Method for Biogenic Monoamines
}

\author{
Hitoshi YoshiKawa（吉川 検）
}

Received December 12, 1969

Since LANGLey established the "neuron theory" (1921), it has been generally accepted that only one neuron exchange takes place between a cholinergic pre- and an adrenergic post-ganglionic fiber in the sympathetic ganglia on the way from the lateral horn cells of the thoracolumber part of the spinal cord to the periphery in the sympathetic nervous system. It has been also well known that adrenaline, exactly noradrenaline (v. EULER, 1946), is the transmitter in almost all the sympathetic postganglionic neurons (FeldBerg and Guddum, 1934; Dale, 1935). However, monoaminergic nerve terminals (HAMBERGER and NORBERG, 1963, 1965) as well as some monoaminergic interneurons (NORBERG and HAMBERGER, 1964) were microscopically demonstrated by the fluorescence method around and among nerve cells in the inferior mesenteric ganglion of the cat. It is now thought that the arrangement of the neuron chains in the sympathetic nervous system is complicated, and requires further fundamental morphological studies.

DAhlström and FuXe (1964), DAhlström $(1965,1967)$, ERÄNKÖ and HäRKÖNEN (1965) already described that the fluorescent material flows from the perikarya to the nerve terminals according to the axoplasmic flow (WeIss and Hiscoe, 1948). In the present paper, the author tried to examine the appearance of the fluorescent material, using dogs axotomized at several levels of the nerve course, in order to elucidate the arrangement and the connections of the sympathetic nerve fibers from the spinal cord to the intestinal wall.

\section{Materials and Methods}

Twelve dogs were used in this study, of which two untreated animals served as controls. The pathway from the communicating rami of the 13th thoracic ganglion via the thoracic greater splanchnic nerve to the splanchnic ganglion and the pathway from the inferior mesenteric ganglion via the colonic nerve to the colonic wall of the dog (cf. STROMBERG, 1967) were studied by fluorescence microscopy in order to clarify the arrangement of the neuron chains in the sympathetic nervous system. Axotomies of the sympathetic nervous system of 10 dogs were performed at several levels under pentobarbital sodium anesthesia. Some of the dogs were treated with nialamide $(500 \mathrm{mg} / \mathrm{kg})$ or reserpine $(5 \mathrm{mg} / \mathrm{kg}) 6 \mathrm{hrs}$ before killing.

Materials examined were as follows: the proximal and distal cut ends of the axotomized nerves, the 13th thoracic, splanchnic and inferior mesenteric ganglia and the nerve element of the colonic wall. The materials and treatments are summarized in Table I. On the 7th day after the operation, when the accumulation of catecholamines was maximal (SANO et al., 1970), all specimens were dissected out under light 
ether or thiopental sodium anesthesia, rapidly frozen in an isopentane dry ice mixture and kept in vacuo for 5 days at a temperature of $-35^{\circ} \mathrm{C}$, one day at $-20^{\circ} \mathrm{C}, 12 \mathrm{hrs}$ at $35^{\circ} \mathrm{C}$ and $1 \mathrm{hr}$ at $60^{\circ} \mathrm{C}$. After freeze-drying, the specimens were transferred to a glass bottle containing granular paraformaldehyde, placed in an oven at a temperature of $80^{\circ} \mathrm{C}$ for $1 \mathrm{hr}$ and then embedded in paraffin in vacuo (FALCK and OwMAN, 1965; HAMBERGer et al., 1965; Corrodi and JoNsSon, 1967).

Table 1. Materials and treatments in the present study.

\begin{tabular}{|c|c|c|c|c|c|c|c|c|c|}
\hline $\begin{array}{l}\text { Site of nerve } \\
\text { section }\end{array}$ & $\begin{array}{l}\text { D } \\
0 \\
0 \\
0 \\
0 \\
0 \\
0 \\
0\end{array}$ & 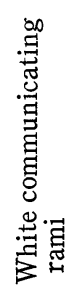 & 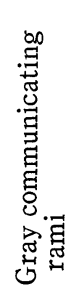 & 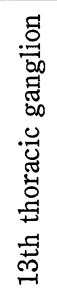 & 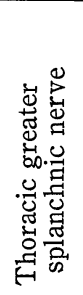 & 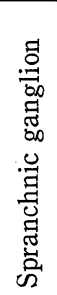 & 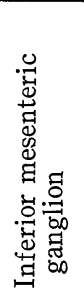 & 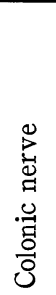 & $\begin{array}{l}\overline{\widetilde{\pi}} \\
\hat{B} \\
.0 \\
0 \\
0 \\
0\end{array}$ \\
\hline None & 2 & 2 & 2 & 2 & 2 & 2 & 2 & 2 & 2 \\
\hline Communicating rami & 2 & 2 & 2 & 2 & & & & & \\
\hline $\begin{array}{l}\text { Interganglionic nerve between } 12 \text { th } \\
\text { and 13th thoracic ganglion }\end{array}$ & 2 & & & 2 & & & & & \\
\hline Thoracic greater splanchnic nerve & 2 & & & 2 & 2 & 2 & & & \\
\hline $\begin{array}{l}\text { All nerves except the colonic nerve } \\
\text { around the inferior mesenteric } \\
\text { ganglion }\end{array}$ & 2 & & & & & & 2 & & \\
\hline $\begin{array}{l}\text { Colonic nerve near the inferior } \\
\text { mesenteric ganglion }\end{array}$ & 2 & & & & & & 2 & 2 & 2 \\
\hline
\end{tabular}

Sections were made at $8 \mu$ thickness and mounted in liquid paraffin after removal of paraffin by xylen. The preparations were studied with an Ultraphot II (Zeiss) equipped with an HBO 200 high pressure mercury lamp, a $3 \mathrm{~mm}$ BG 12 excitation filter, a dark field condenser for immersion oil, and a $500 \mathrm{~m} \mu$ barrier filter. After examination and photography in the fluorescence microscope the sections were also examined phase-contrast microscopically. A series of adjacent sections were stained with hematoxyline-eosin or toluidine blue as controls.

\section{Observations}

\section{A. Normal Condition}

\section{The 13th thoracic ganglion and its communicating rami}

The 13th thoracic ganglion in the dog located ventrolateral to the 13th thoracic vertebra, is ca. $7 \mathrm{~mm}$ long, flat and ovoid in shape and usually connected by two white and two gray communicating rami with the 12th and 13th thoracic and 1st lumbar nerves. Two gray communicating rami start from near the upper pole of the ganglion: one ascends and connects with the 12th thoracic nerve and the other descends and connects with 13th thoracic nerve. They are both joined together with the 
anterior branches somewhat peripheral to the diverging point of the anterior and posterior branches of the spinal nerve. Two white communicating rami start from near the origin of the anterior branches of the 13th thoracic and 1st lumbar nerve and penetrate into this ganglion near its lower pole. The gray communicating ramus joins the spinal nerve always 1 to $2 \mathrm{~mm}$ proximal to the origin of the white communicating ramus from the spinal nerve. Figure 1 represents these findings schematically.

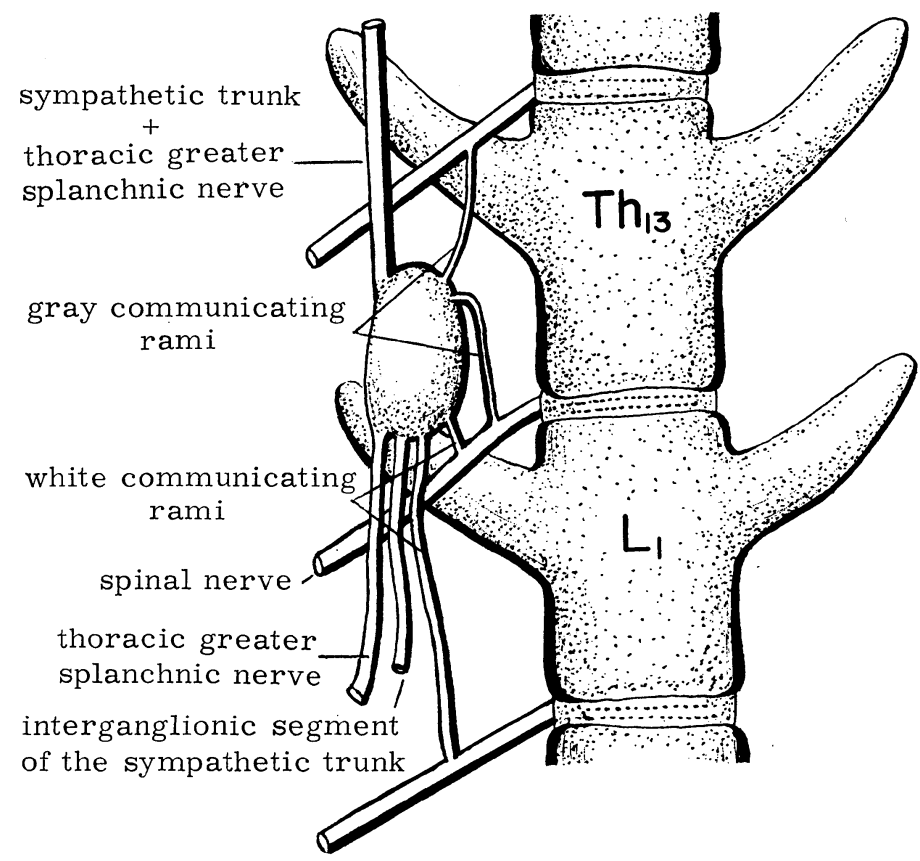

Fig. 1. Schema showing the relationship between the 13th thoracic ganglion and its communicaing rami. The two gray communicating rami start from near the upper pole of this ganglion; one ascends to connect with the 12th thoracic nerve and the other with the 13th thoracic nerve. The two white communicating rami start from near the origin of the anterior branches of the 13th thoracic and 1st lumbar nerve and penetrate into this ganglion near its lower pole.

a. The white communicating ramus is chiefly composed of myelinated fibers of small diameter. A small number of myelinated fibers of large or medium diameter are scattered among them. Their myelin sheaths show a faintly green autofluorescence which is distinguished from the yellowish green fluorescence characteristic of catecholamine.

b. The gray communicating ramus is mainly composed of non-myelinated nerve fibers which show the faint yellowish green fluorescence of catecholamine. A few myelinated nerve fibers are scattered among them.

c. The 13th thoracic ganglion is chiefly composed of nerve cells that are spherical or ovoid in shape and $15-60 \mu$ in diameter. Specific yellowish green fluorescent granules are contained in the cytoplasm of most of the nerve cells, but not of all. 
The fluorescence was rather intense in a minority of the cells, whereas it was of medium or low intensity in most of them. Larger axons of the nerve cells exhibited a very faint fluorescence (Fig. 2). Some nerve cells without yellowish green fluorescence

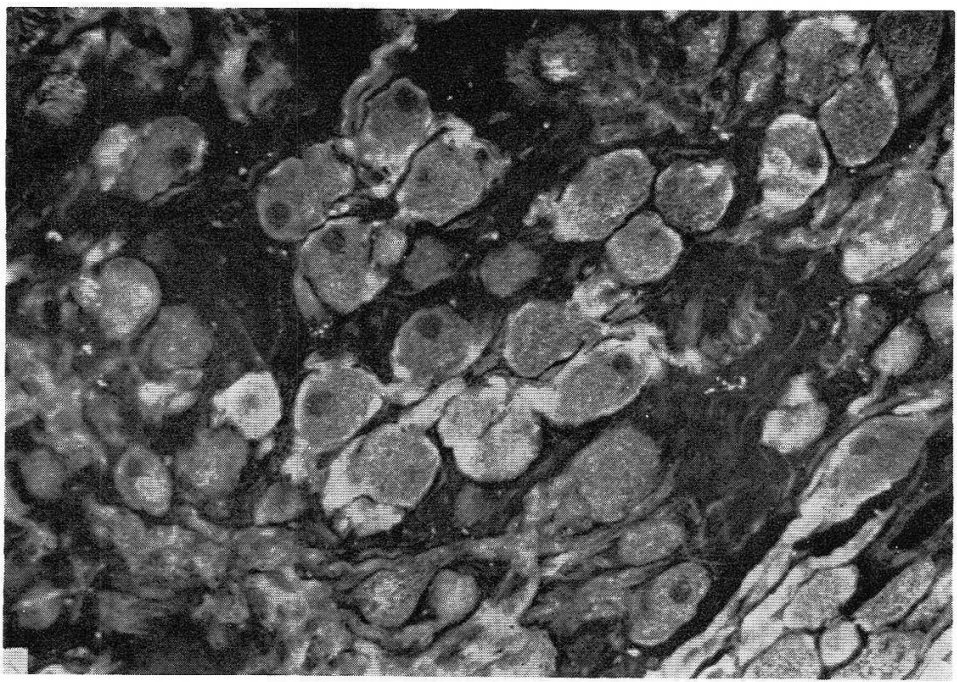

Fig. 2. 13th thoracic ganglion, dog, in normal condition. Catecholamine fluorescent nerve cells of various intensities are visible. $\times 350$

were scattered among the yellowish green fluorescent ones (Fig. 3 a), but other nerve cells without yellowish green fluorescence appeared constantly as a group along the white communicating rami and in its penetrated region (Fig. 3 b). About half of the catecholamine-less nerve cells contained yellowish brown autofluorescent granules in their cytoplasm. The distribution of the nerve cells with or without yellowish green fluorescence is shown in Figure $3 \mathrm{c}$. Monoaminergic nerve terminals with typical varicosities were noted around and among the nerve cells. They were not related to the blood vessels. Small intensely fluorescent cells (SIF-cells) were noted in the ganglion. A few to some tens of such cells were located in well defined areas inside of the ganglion or among the axons outside of it. They were ovoid in shape, 8 to $15 \mu$ in diameter with large nuclei which were somewhat eccentrically located. The fluorescence exhibited by these SIF-cells was generally more intense than that of the nerve cells, though variable from cell to cell. It was not decided whether these cells are realy nerve cells or not.

\section{The thoracic greater splanchnic nerve}

This nerve consists of faintly green autofluorescent myelinated nerve fibers of varying diameters intermingled with faintly yellowish green fluorescent nonmyelinated nerve fibers.

\section{Splanchnic and inferior mesenteric ganglion}

There is no essential difference between the histological findings of these prevertebral ganglia and those of the thoracic onse. Monoaminergic nerve terminals appeared more abundantly in the prevertebral ganglia than in the thoracic ones (Fig. 4). Sometimes short axons of the fluorescent nerve cells terminated in close contact 
with adjacent nerve cells (Fig. 5). There is no tendency for groups of the nerve cells without yellowish green fluorescence to appear in connection with the communicating branch as in the 13th thoracic ganglion. Adjacent to the capsule of the inferior
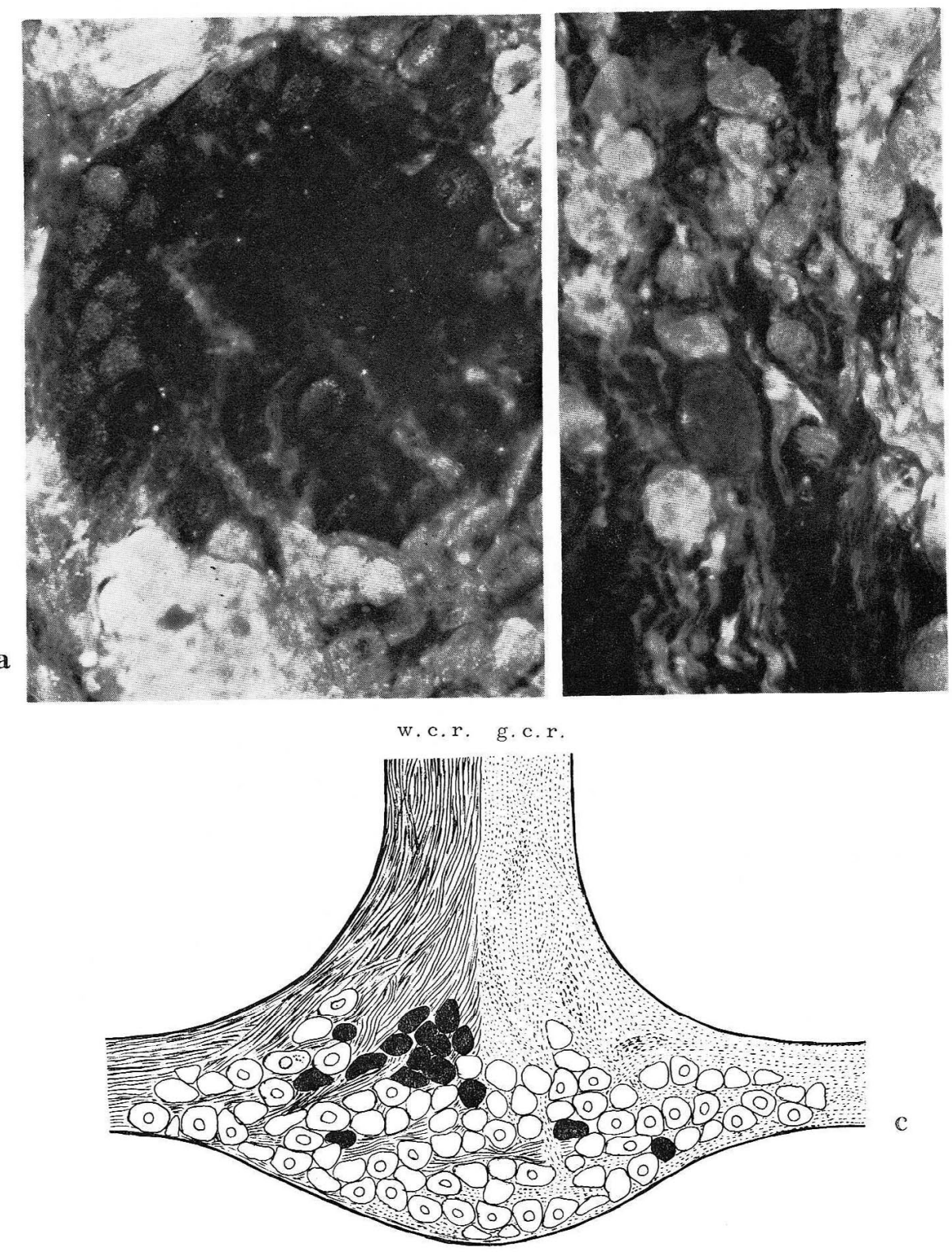

Fig. 3. a, b and c. 13th thoracic ganglion, dog, in normal condition. a, A catecholamine-less nerve cell among catecholaminergic nerve cells. b, A group of catecholamine-less nerve cells. $\times 350 \mathbf{c}$, Schematic representation of the nerve cells with or without yellowish green fluorescence. g. c. $r$ gray communicating ramus, $w$. c. $r$ white communicating ramus. 


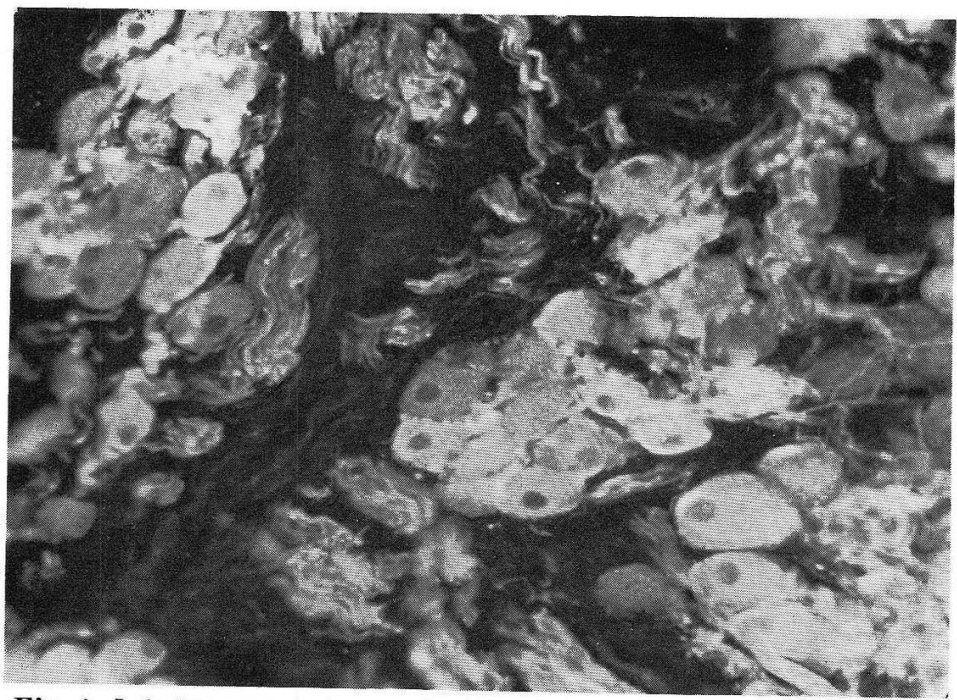

Fig. 4. Inferior mesenteric ganglion, dog, in normal condition. Fluorescent nerve terminals are visible around some fluorescent nerve cell bodics. $\times 350$

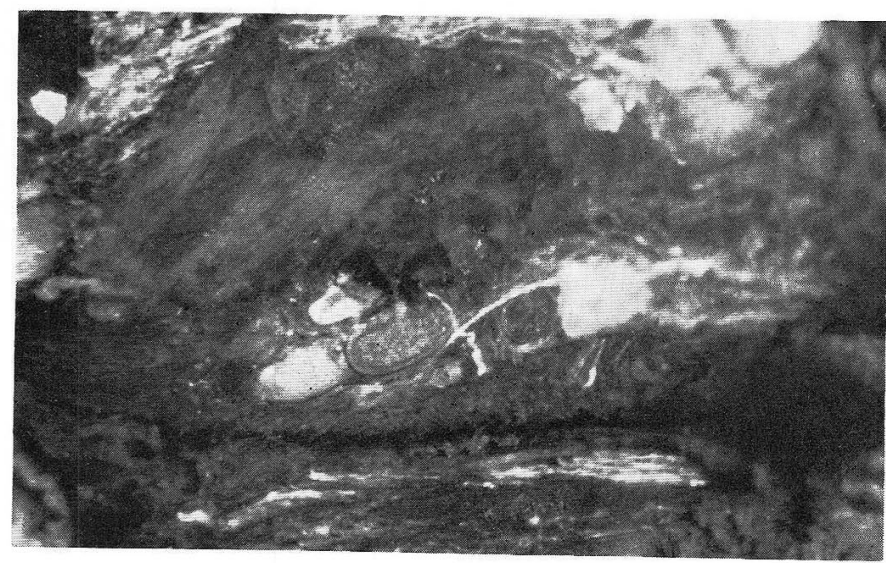

Fig. 5. Inferior mesenteric ganglion, dog, in normal condition. The axon of a catecholamine fluorescent nerve cell body terminates on an adjacent catecholamine-less nerve cell body. $\quad \times 350$

mesenteric ganglion, paraganglia occurred constantly in clusters. Paraganglion cells about $6-10 \mu$ in diameter, appeared mostly like asymmetrical tear drops and showed yellow fluorescence in various degree.

\section{Colonic nerve}

This nerve consists of non-myelinated nerve fibers with faintly yellowish green fluorescence and few autofluorescent myelinated ones.

\section{Colonic wall}

An abundance of yellowish green fluorescent substances was observed in Auerbach's plexuses. Some of them were identified as nerve fibers. The fluorescent 
nerve fibers took two different pathways: Some followed the direction of the circular muscle layer, while others penetrated the muscle layer towards the submucosa to enter Meissner's plexuses. The ganglion cells of Auerbach's plexuses which were spherical in shape and about $20 \mu$ in diameter did not fluoresce. Some ganglion cells were surrounded by fluorescent nerve terminals. Meissner's plexuses whose ganglion cells were non-fluorescent were enveloped by faintly yellowish green fluorescent fibers. The other findings corresponded to those noted in Auerbach's plexus. In the wali of the arteries which were near the plexuses monoaminergic vasomotor nerve fibers were observed.

\section{B. Experimental Conditions}

\section{Pharmacological}

a. Administration of nialamide resulted in: 1) an augmentation of catecholamine fluorescence of the monoaminergic neurons in the sympathetic ganglia and in the peripheral nerves examined, 2) a decrease in the number of the isolated catecholaminefree nerve cells in the 13th thoracic, splanchnic and inferior mesenteric ganglia, and 3 ) little change in the group of nerve cells primarily free of the catecholamine fluorescence in the definite areas of the 13th thoracic ganglion.

b. Administration of reserpine caused in $6 \mathrm{hrs}$ an almost complete loss of the catecholamine fluorescence of the monoaminergic neurons in the sympathetic ganglia. It took $24 \mathrm{hrs}$ for the accumulation of catecholamine in the proximal cut end of the nerves to disappear.

\section{Operative}

a. Section of the communicating rami of the 13th thoracic ganglion

Seven days after the operation, the proximal and distal cut ends of the white and gray communicating rami were removed for examination. No accumulation of the yellowish green fluorescent material was noted at the cut ends on either the spinal or the ganglionic side of the white communicating rami, nor at the cut end of the spinal side of the gray communicating rami. The yellowish green fluorescence was noted only at the cut end of the ganglionic side of the gray communicating rami (Fig. 6). The nerve cells without catecholamine fluorescence were increased in number in the 13th thoracic ganglion with the white and gray communicating rami sectioned, in comparison with the unsectioned ganglion.

b. Section of the thoracic greater splanchnic nerve

The thoracic greater splanchnic nerve was sectioned bilaterally just before it penetrated the diaphragm. The accumulation of yellowish green fluorescent material was found at the proximal cut end of this nerve for several $\mathrm{mm}$ proximal to it, but not at the distal cut end. The nearer to the proximal cut end, the more was the fluorescent material. At larger magnification, these yellowish green fluorescent nerve fibers were scattered among the faintly green autofluorescence of the myelinated nerve fibers and were swollen towards the cut end (Fig. 7). After the sectioning, the catecholamine-free nerve cells were increased in number in the 13th thoracic and splanchnic ganglia, as compared with the unsectioned ganglia.

c. Section of the nerve fibers which enter and leave the inferior mesenteric ganglion

After preganglionic denervation monoaminergic nerve terminals were markedly 


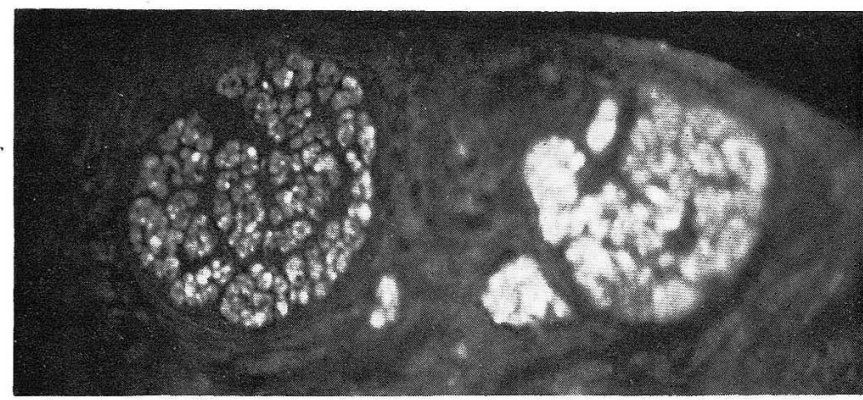

Fig. 6. Proximal cut end (cross section) of the gray communicating rami of the 13th thoracic ganglion, dog, 7 days after section of the above described rami. Accumulation of catecholamine is noted. $\times 125$

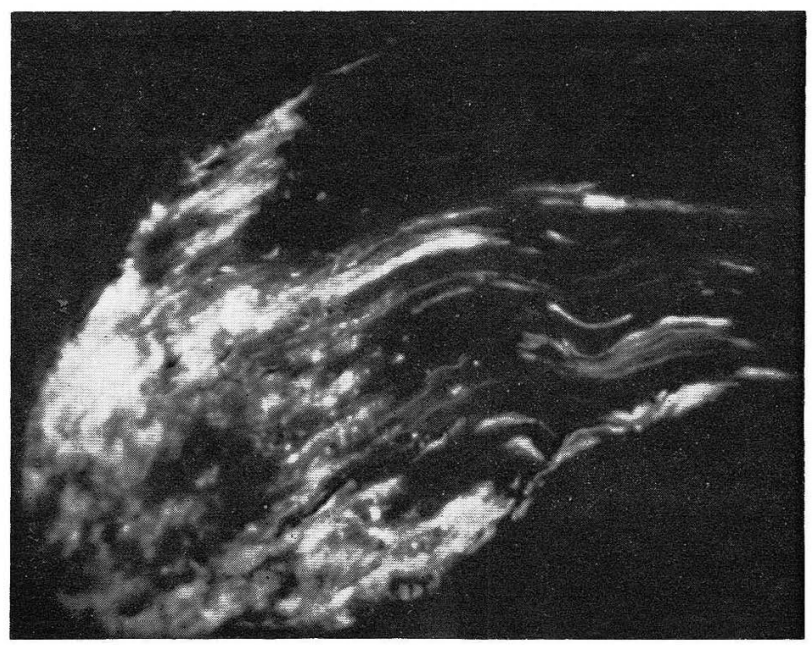

Fig. 7. Proximal cut end (longitudinal section) of the thoracic greater splanchnic nerve, dog, 7 days after section of the abovedescribed nerve. Accumulation of catecholamine is noted. $\times 125$

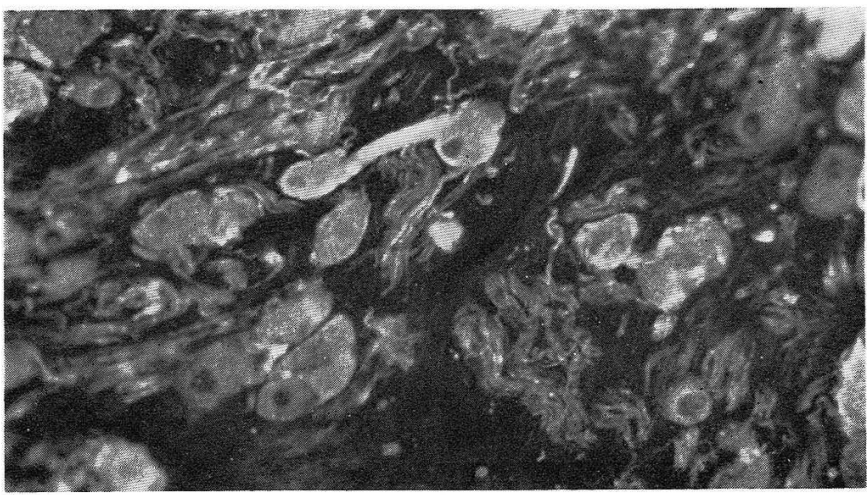

Fig. 8. Inferior mesenteric ganglion, dog, 7 days after preganglionic denervation. The axon of a catecholamine fluorescent nerve cell body terminates on an adjacent catecholamine fluorescent nerve cell body. Many other nerve cell bodies do not lose catecholamine fluorescence. 
decreased in number in the inferior mesenteric ganglion, whereas the number of the catecholamine fluorescent nerve cell bodies were only a little decreased (Fig. 8). After postganglionic denervation, almost all nerve cells that were catecholaminefluorescent in the normal condition lost their fluorescence. Monoaminergic nerve terminals were, however, still recognized in normal numbers among the nerve cell bodies of the inferior mesenteric ganglion (Fig. 9). Yellow fluorescence in the

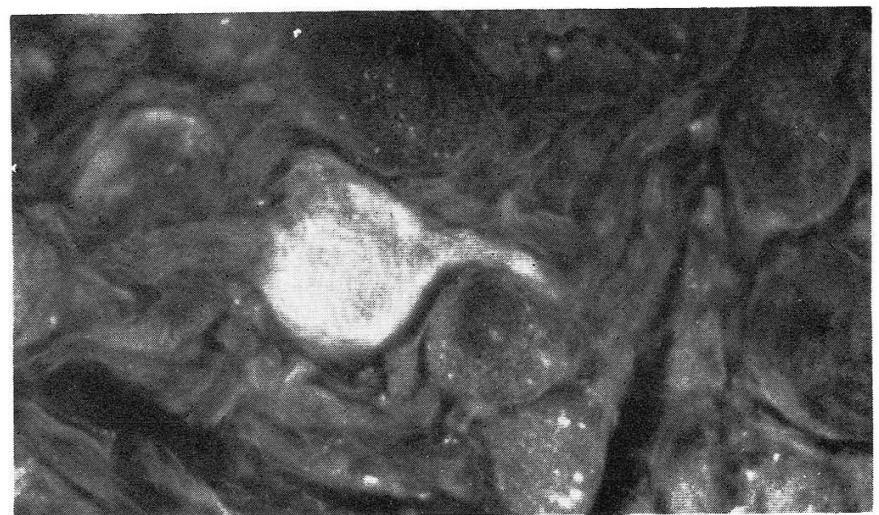

Fig. 9. Inferior mesenteric ganglion, dog, 7 days after postganglionic denervation. The axon of a catecholamine fluorescent nerve body terminates on an adjacent catecholamine-less nerve cell body. Other nerve cell bodies lose catccholamine fluorescence $\times 400$

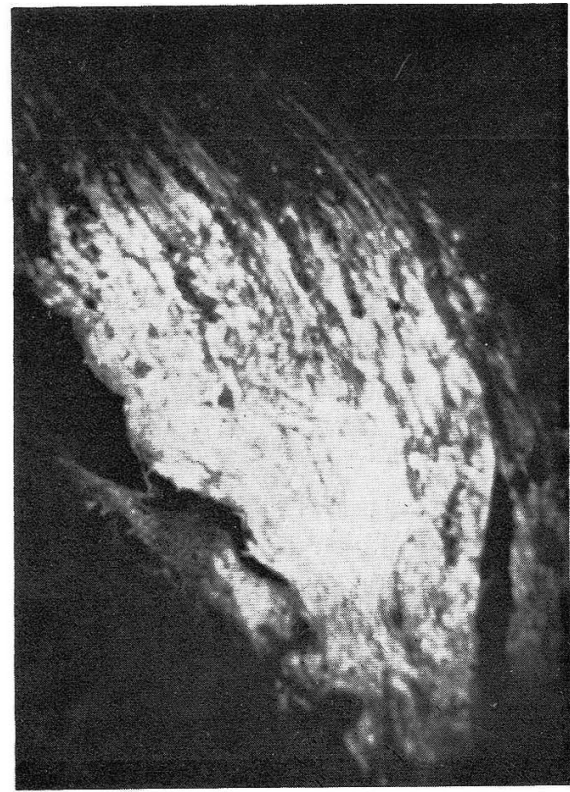

$\mathbf{a}$

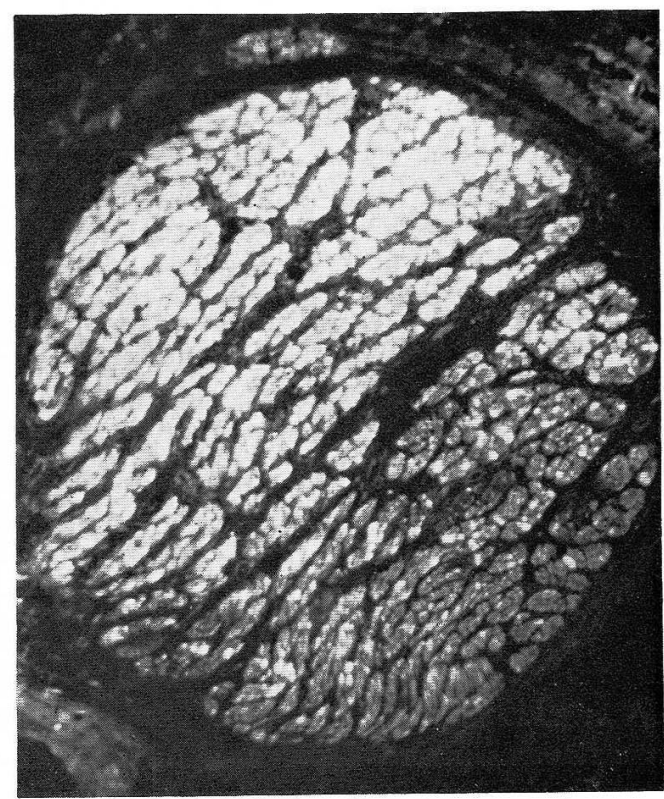

b

Fig. 10. a and b. Proximal cut end of the colonic nerve, dog, 7 days after section of above-described nerve. Accumulation of catecholamine is noted. a. longitudinal section, b. cross section. $\times 280$ 
perikarya of paraganglion cells remained unaffected.

d. Section of the colonic nerve

The accumulation of yellowish green fluorescent material was noted in the swollen non-myelinated nerve fibers at the proximal cut end of the colonic nerve when it was examined on the 7 th day after axotomy (Fig. 10. a, b). Almost no fluorescence was noted at the distal cut end of the nerve. The catecholamine fluorescent nerve terminals, on the other hand, had disappeared from both Auerbach and Meissner plexuses after axotomy.

The above-described results are summarized in Table 2.

Table 2. Effects of axotomy on monoaminergic nerve cells and terminals

\begin{tabular}{|c|c|c|c|c|c|}
\hline & & \multirow[b]{2}{*}{ Control } & \multicolumn{3}{|c|}{ Axtomy in the: } \\
\hline & & & $\begin{array}{l}\text { Interggl. nerve Thoracic greater } \\
\text { between } 12 \text {. and splanchnic nerve } \\
\text { 13. thoracic ggl. }\end{array}$ & $\begin{array}{l}\text { Nerve except } \\
\text { the colonic nerve } \\
\text { around the inf. } \\
\text { mesenteric ggl. }\end{array}$ & $\begin{array}{l}\text { Colonic } \\
\text { nerve }\end{array}$ \\
\hline \multirow{2}{*}{ 13. thoracic ggl. } & $\mathrm{Cm}$ & present & decreased & & \\
\hline & $\mathrm{Tm}$ & present & decreased & & \\
\hline \multirow{2}{*}{$\begin{array}{l}\text { Splanchnic } \\
\text { ggl. }\end{array}$} & $\mathrm{Cm}$ & present & decreased & & \\
\hline & $\mathrm{Tm}$ & present & decreased & & \\
\hline \multirow{2}{*}{$\begin{array}{l}\text { Inferior } \\
\text { mesenteric } \\
\text { ggl. }\end{array}$} & $\mathrm{Cm}$ & present & & $\begin{array}{l}\text { slightly } \\
\text { decreased }\end{array}$ & $\begin{array}{l}\text { markedly } \\
\text { decreased }\end{array}$ \\
\hline & $\mathrm{Tm}$ & present & & $\begin{array}{l}\text { markedly } \\
\text { decreased }\end{array}$ & $\begin{array}{l}\text { slightly } \\
\text { decreased }\end{array}$ \\
\hline \multirow{2}{*}{ Intramural ggl. } & $\mathrm{Cm}$ & absent & & & unchanged \\
\hline & $\mathrm{Tm}$ & present & & & disappeared \\
\hline
\end{tabular}

$\mathrm{Cm}$ : monoaminergic nerve cell Tm: monoaminergic terminal

\section{Discussion}

In order to clarify the arrangement of the neuron chain in the sympathetic nervous system, one must first select some nervous pathways for study which can be easily and unequivocally followed from the communicating rami to the effect organ. In this study two kinds of pathways were examined: 1) From the 4th lumbar ganglion and its communicating rami via the lumbar splanchnic nerve, inferior mesenteric ganglion and colonic nerve to the intramural ganglia of the colon wall. 2) From the 13th thoracic ganglion and its communicating rami via the thoracic greater splanchnic nerve to the splanchnic ganglion. Each of the above-described pathways has both advantages and disadvantages for the present purpose. The first has two disadvantages: The communicating rami show wide anatomical individual variations and the lumber splanchnic nerve is too thin to treat easily by means of various operations. However, it has the following advantages: The course from the inferior mesenteric ganglion via the colonic nerve to the colon wall is easily submitted to pre- and postganglion denervation and the changes are easily followed after surgery. The second course has two advantages: The communicating rami of the 13th thoracic ganglion 
are easy to find and show few individual anatomical variations. The thoracic greater splanchnic nerve is thick enough to be easily identified and sectioned. It has, however, the following disadvantages: After the thoracic greater splanchnic nerve reaches the splanchnic ganglion, selective axotomy of the postganglionic nerve fibers are impossible. The postganglionic fibers form such a reticulum that accurate identification and tracing are impossible. Thus, the most advantageous level of each course was used: From the communicating rami to the prevertebral ganglion, the second course was adopted. From the prevertebral ganglion to the effect organ, the first course was adopted.

Using DAHLSTRÖM-FuXE's method (1964 a) by which monoaminergic nerve fibers in the peripheral nerve can be visualized, the inferior mesenteric ganglion, the colonic nerve and the intestinal wall of the dog were observed at regular intervals after section of the colonic nerve, and the following findings which were most manifest 7 days after the section were obtained: 1) loss of catecholamine fluorescence of the cell body proximal to the cut end. 2) an accumulation of catecholamine at the proximal cut end of the axon. 3) loss of catecholamine fluorescence of the distal nerve terminals (SANo et al., 1970). Following this preliminary study, specimens were examined from various parts of the sympathetic nervous system between the spinal cord and the colon and the following findings were obtained: Preganglionic section results in a remarkable decrease in the number of monoaminergic nerve terminals in the inferior mesenteric ganglion, whereas postganglionic section results in loss of catecholamine fluorescence of almost all the nerve cell bodies in the inferior mesenteric ganglion and little change in the number of monoaminergic nerve terminals. It is interesting that a few monoaminergic nerve terminals still remained in the inferior mesenteric ganglion even after preganglionic section and a few fluorescent nerve cells remained in the inferior mesenteric ganglion even after postganglionic section. These findings suggested that some of the fluorescent terminals belonged to the short axon of monoaminergic nerve cells in the same ganglion. In fact, in the 13th thoracic and also inferior mesenteric ganglia, we were able to observe some axons of fluorescent nerve cells terminating on adjacent nerve cells in the same ganglion. Therefore, the origins of these monoaminergic nerve terminals were thought to be intra- and extraganglionic. NoRBERG and SJÖQvisT (1966) also noted that monoaminergic nerve terminals were richly distributed in the inferior mesenteric ganglion of the cat, traced them by means of the axotomy experiment, and concluded that the origin of all of them was intraganglionic. Our present results agree with those of NORBERG and SJÖQVIST in so far as demonstrating the presence of intraganglionic monoaminergic interneurons.

According to Hamberger and Norberg $(1963,1965)$ and Hamberger et al. (1965), sympathetic ganglion cells have catecholamine-specific fluorescence of various intensities. This fluorescence means the existence of monoaminergic neurons and the differences in the intensity of the fluorescence would depend on the functional phase of each cell. In this study, sympathetic ganglia of normal animals were composed of nerve cells with and without catecholamine fluorescence. The latter nerve cells appear singly or in groups. After the administration of nialamide these isolated catecholamine-free nerve cells are decreased in number, as observed by NoRBERG (1965). Therefore, it is highly probable that some of them are essentially monoaminergic and have lost only temporarily their monoamine due to their functional 
phase. Some other nerve cells which show no catecholamine fluorescence even after administration of nialamide, however, appear constantly forming a group in a definite area of the 13th thoracic ganglion and are considered to be essentially non-monoaminergic.

In their study of the inferior mesenteric ganglion of the cat, NoRBERG and SJÖQVIST (1966) built up the following hypothesis: Preganglionic fibers, having their cell bodies in the spinal cord, are cholinergic and terminate in a prevertebral ganglion. Postganglionic fibers, having their cell bodies in a prevertebral ganglion, are adrenergic and terminate in the cholinergic intramural ganglia of the gastro-intestinal tract. We also made up a schema of the possibilities of the neuron chain in the sympathetic nervous system. On the basis of the findings which were obtained in our study, the possible arrangement of the neuron chain may be considered as follows. As shown in Figure 11, preganglionic nerve fibers, originating from the spinal cord, are nonmonoaminergic and terminate around nerve cells in the para- or prevertebral ganglia which contain monoaminergic and non-monoaminergic neurons $(a, b, c$ and $d$ ).

\begin{tabular}{|c|c|c|c|}
\hline spinal cord & $\begin{array}{c}\text { paravertebral } \\
\text { ganglion }\end{array}$ & $\begin{array}{l}\text { prevertebral } \\
\text { ganglion }\end{array}$ & $\begin{array}{l}\text { effect organ } \\
\text { (colon wall) }\end{array}$ \\
\hline
\end{tabular}

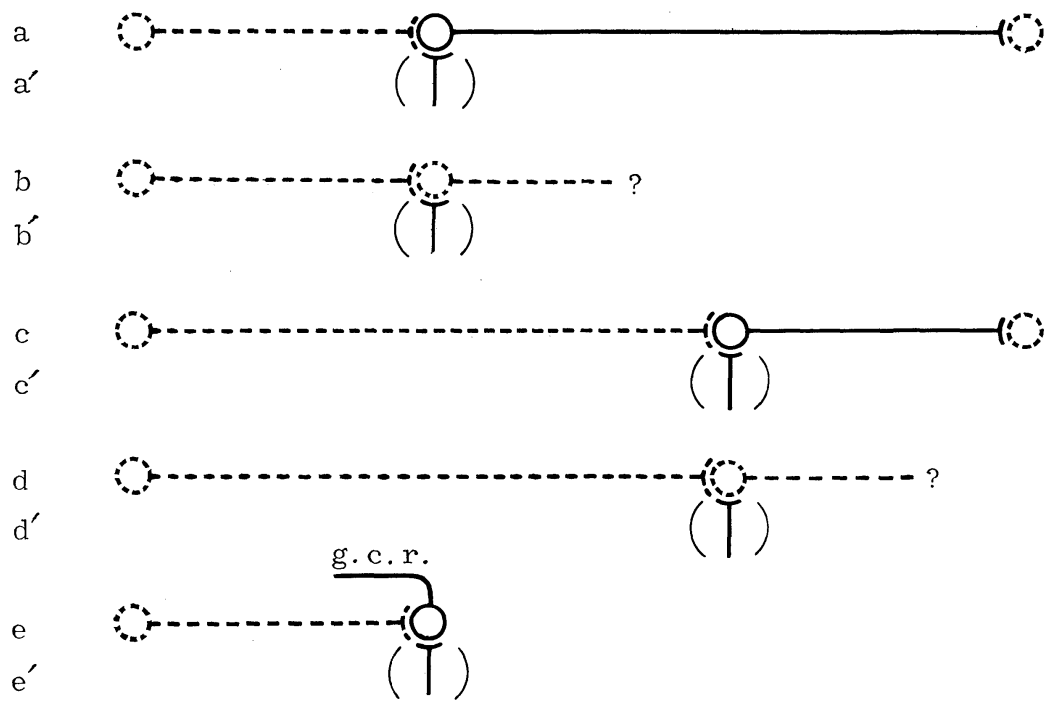

Fig. 11 Possible pathways from the spinal cord to the colon wall. Monaminergic neurons are presented by a solid line and non-monoaminergic ones by a broken line.

The monoaminergic postganglionic fibers may go directly to the effect organ, to lower ganglia, to adjacent nerve cells in the same ganglion, or only in the case of the thoracic ganglia, to gray communicating rami $(e)$. To sum up, there are five possible courses as seen in Figure 11. The intra- or extra-ganglionic monoaminergic nerve terminals around their cell bodies were occasionally recognized. In due consideration of this, there are five pathways more as shown with (T) in Figure $11\left(a^{\prime}, b^{\prime}, c^{\prime}, d^{\prime}\right.$ and $\left.e^{\prime}\right)$.

Finally, the axotomy of the thoracic greater splanchnic, the lumbar splanchnic 
or the colonic nerve did not cause the accumulation of catecholamine at the distal cut ends. These findings deny the existence of the afferent monoaminergic nerve in these nerves.

\section{Summary}

The arrangement of the neuron chains was studied by the fluorescence histochemical method of FALCK and HILLARP, to elucidate the distribution of monoamine containing nerve cells and the connection between nerve fibers in the sympathetic nervous system of the dog. Communicating rami and thoracic greater splanchnic nerve which center in the 13th thoracic ganglion, prevertebral ganglia, colonic nerve and intramural ganglia were subjected to observation. Section of nerves at various levels and administration of drugs affecting the metabolism of monoamines (reserpine and nialamide) were performed in addition to normal controls. The results obtained were as follows.

1. Monoaminergic fibers are not contained in the white communicating rami.

2. Non-monoaminergic nerve cells are found singly or in groups among fluorescent ones in both the para- and prevertebral ganglia (splanchnic and inferior mesenteric ganglia). Especially, they group in a definite region of the 13th thoracic ganglion where the white communicating rami penetrate.

3. Efferent monoaminergic nerve fibers are contained in the gray communicating rami, splanchnic and colonic nerve.

4. Monoaminergic nerve terminals are found around monoaminergic and nonmonoaminergic nerve cell bodies in both the para- and prevertebral ganglia.

5. There are two types of monoaminergic postganglionic fibers, namely short and long ones. The short axons terminate in the same ganglion where its own mother cell body is located, while long ones in a distant ganglion or intramural ganglia.

6. Nerve cells are non-fluorescent in the intramural ganglia of both Auerbach's and Meissner's plexuses.

From the above-described results ten defferent pathways, including five main and five subsidary ones, were proposed for the arrangement of the neuron chain from the lateral horn of spinal cord to the intestinal wall.

Acknowledgments The author wishes to thank Prof. Y. SANo for his kind guidance and encouragement throughout this study. He is also indebted to Dr. J. Ochi for his advice and help in the preparation of this manuscript.

\section{生体モノアミンのための螢光顕微鏡的検出法による交感神経ノイロン鎖の 実験的研究 (内容自抄)}

FALCK-HiLlaRP 法を用いて，モノアミン含有ノイロンの分布とその線維連絡を追求 し，交感神経系におけるノイロン連鎖のあり方を検討した．材料としてはイスが用い られ，第13胸椎の高さにある幹神経節を中心に，乙れに接続する交通枝，大内臟神経， 椎前神経節，結腸神経 ならびに腸の壁内神経丵が検索された．実験的には 種々の高さ における節前ならびに節後線維の切断，モノアミン代謝に関与するレゼルピンならびに ナイアラマイドの投与を行なった. 
1. 白交通枝はモノアミン含有線維を含まない。

2. 椎旁および椎前神経節（内臓および下腸間膜神経節）では，いずれもモノアミン 含有ノイロンにまざって，モノアミンを全く含まない神経細胞が存在する，非モノアミ ン作動性神経細胞は孤立性にあるいはグループをなして出現するが，とくに椎旁神経節 では 白交通枝の進入部位で集団をなす傾向がある.

3. 灰白交通枝, 大内臓神経 および結腸神経には, 遠心性のモノアミン作動線維が含 まれている。

4. 椎旁および椎前神経節においては, モノアミン含有神経細胞にも 非含有神経細胞 にも，その周部に終末するモノアミン作動線維がみとめられる.

5. 神経節を形成するモノアミン作動性神経細胞から出た節後線椎は, 短いものはそ の神経節の中で, 長いものは遠隔の神経節の中または壁内神経節において終末する.

6. 壁内神経節は, アウエルバッ八, マイスネルともに 非螢光性神経細胞から形成 されている。

7. 以上のような研究結果を総合し，脊髄側角にはじまり，消化管壁に分布する交感 神経系におけるノイロン連鎖の状態を 5 つの基本型と 5 つの亜型, 計 10 型に分類した.

\section{References}

Corrodi, H. and G. Jonsson: The formaldehyde fluorescence method for the histochemical demonstration of biogenic monoamines. A review of methodology. J. Histochem. Cytochem. 15: 65-78 (1967).

Dale, H. H.: Pharmacology and nerve endings. Proc. Roy. Soc. Med. 28: 319-332 (1935).

Dahlström, A. and K. Fuxe: A method for the demonstration of adrenergic nerve fibers in peripheral nerves. Z. Zellforsch. 62: 602-607 (1964).

: Observations on the accumulation of noradrenaline in the proximal and distal parts of peripheral adrenergic nerves after compression. J. Anat. (Lond.) 99: 677-689 (1965).

- - The effect of reserpine and tetrabenazine on the accumulation of NA in the rat sciatic nerve after ligation. Acta physiol. scand. 69: 167-179 (1967).

Eränkö, 0. and M. Härkönen: Effect of axon division on the distribution of noradrenaline and acetylcholinesterase in sympathetic neurons of the rat. Acta physiol. scand. 63: 411-412 (1965).

Euler, U. S. v.: A specific sympathomimentic ergone in adrenergic nerve fibers and its relations to adrenaline aed noradrenaline. Acta physiol. scand. 12: 73-93 (1946).

Falck, B. and Ch. Owman: A detailed methodological description of the fluorescence method for the cellular demonstration of biogenic monoamines. Acta Univ. Lund II. 7: 1-23 (1965).

Feldberg, W. and J. H. Gaddum: The chemical transmitter at synapses in a sympathetic ganglion. J. Physiol. (Lond.) 81: 305-319 (1934).

Hamberger, B. and K.-A. Norberg: Monoamines in sympathetic ganglia studied with fluorescence microscopy. Experientia 19: 580-581 (1963).

-: Studies on some systems of adrenergic synaptic terminals in the abdominal ganglia of the cat. Acta physiol. scand. 65: 235-242 (1965).

Hamberger, B., K. -A. Norberg and U. Ungerstedt: Adrenergic synaptic terminals in autonomic ganglia. Acta physiol. scand. 64: 258-286 (1965).

Härkönen, M.: Carboxylic esterases, oxidative enzymes and catecholamine in the superior cervical ganglion of the rat and the effect of pre- and postganglionic nerve division. Acta physiol. scand. 
63 ad. Suppl. 237: 9-94 (1964).

Langley, J. N.: The autonomic nervous system. Part 1. Cambridge, W. Hefter and Sons, 1921.

Norberg, K.-A.: Drug-induced changes in monoamine levels in the sympathetic ganglion cells and terminals. Acta physiol. scand. 65: 221-234 (1965).

Norberg, K. -A. and B. Hamberger: The sympathetic adrenergic neuron. Some characteristics revealed by histochemical studies on the intraneuronal distribution of the transmitter. Acta physiol. scand. 63 ad. Suppl. 238: 1-42 (1964).

Norberg, K. -A. and F. Sjöqvist: New possibilities for adrenergic modulation of ganglionic trasmission. Second symposium on catecholamines. 18: 743-751 (1966).

Sano, Y., H. Yoshikawa and J. Ochi: Intraneuronal shift of catecholamines as revealed by fluorescence and electron microscopy. Arch. histol. jap., in press.

Stromberg, M. W.: The autonomic nervous system. Chapt. 12 in M. E. Miller, G. C. Christensen and H. E. Evans: Anatomy of the dog. Philadelphia-London, W. B. Saunders Co. 1967

Weiss, P. and H. B. Hiscoe: Experiments on the mechanism of nerve growth. J. exp. Zool. 107: 315-395 (1948). 